\title{
ARISTIDA PLUMOSA (LINN.): ITS ALLELOPATHIC EFFECTS AND SAND FIXING ABILITY AT BALOUZA, NORTH SINAI, EGYPT
}

\author{
Elkharbotly, Anwar A. ${ }^{1}$ and Mohamed A. Balah ${ }^{2 *}$ \\ ${ }^{1}$ Department of Sand Dunes, Desert Research Center, Matareya, \\ Cairo, Egypt \\ ${ }^{2 *}$ Department of Plant Protection, Desert Research Center, Matareya, \\ Cairo, Egypt \\ *E-mail: mbaziz1974@gmail.com
}

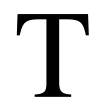

he present investigation aimed at focusing on the efficiency of Aristida plumosa Linn. as an ideal dune fixer at Balouza area, North Sinai, Egypt. Measurements of nebkha and canopy characteristics during different developmental stages in 2014 were accomplished, in addition, sand trapped mass, shoot and root biomass and sand aggregation adherent around roots were determined. The allelopathic effect of root and rhizosphere extracts of A. plumosa on seed germination percentage and early growth of Portulaca oleracea L. and on its shoot and root development was studied. In addition, phenolic compounds in root tissue and rhizosphere, microorganisms density in rhizosphere and nonrhizosphere soil beneath A. plumosa were studied. Dune plant communities were also surveyed and analysed at the studied region. Shoot elongation rate of A. plumosa exceed sand trapped rate, it recorded 2.67, 4.33 and $2.11 \mathrm{~mm}^{-1 a y}{ }^{-1}$ from sand deposition. Shoot biomass reached $165.8 \mathrm{~g} \mathrm{~m}^{-2}$, root biomass was $12.82 \mathrm{~g} \mathrm{~m}^{-2}$ and sand aggregates around roots recorded $7.25 \mathrm{~g} \mathrm{~m}^{-2}$. The negative effects observed in $P$. oleracea root growth traits were higher from root extracts than soil rhizosphere extracts, whereas shoot length and germination of $P$. oleracea were most affected by rhizosphere extracts than root extracts. Phenol extracted by methanol subjected to HPLC/UV qualitative analysis and revealed that coumaric and resorcinal acids were found in both root and rhizosphere extracts, but in higher concentrations in former one. Bacterial count was significantly higher than number of fungi in the soil near A. plumosa grass. However, total microorganisms density was significantly higher in rhizosphere soils compared with non-rhizospheric samples.

Keywords: sand dunes, vegetation, allelopathic activity, soil microorganisms 
Sand dunes occupy most of the coastal zone of North Sinai, Egypt, and their plants are well adapted to grow in full sunshine and nutritionally poor soil, due to their extensive root system, which stabilize sandy soils in an unstable and harsh habitat. In these habitats, plants suffer several stresses and exhibit a unique adaptations to plant burial and exposure of roots by moving sand grains by the wind action, salt spray, dryness and nutrient deficiency (Danin, 1991, 1996a and 1996b and Hesp, 1991).

Several studies have been done on the floristic composition of North Sinai (Boulos, 1960; Täckholm, 1974 and Gazar et al., 2000). Plant species familiar to sand dune habitat of Balouza, North Sinai are as follow; Zygophyllum album, Mesembryanthemum crystallium in dune crest and dune slope, however, Stipagrostis plumosa was found in dune crest. Whereas, Cornulaca monocantha was found in the foot of dune. Nebkha of S. plumosa was the largest nebkha dimensions followed by nebkha of Zygophyllum album, while the lowest nebkha dimensions were recorded for Mesembryanthemum crystallium (Elkharbotly, 2013). The presence of rhizosheaths may be an adaptation to nutritional stress and dry conditions (Wullstein et al., 1979 and Barbour et al., 1987). Rhizosheaths are structures composed of mucilage secreted from plants and adherent soil particles that form a cylinder around the root and the attachment of sand grains to the roots in the dry regions (Metcalf, 1960). Perennial roots of Lyginia barbata are covered by a thick sheath of sand grains trapped tightly by long, tangled, persistent root hairs. This sand sheath effectively doubles the diameter of the root. Sand sheaths of Lyginia and other perennial monocotyledons growing in desert and sand dune habitats have been implicated in protection against desiccation and heat stress, especially during summer (Shane et al., 2010). The formation of the sheaths depends entirely on the numerous living root hairs, which extend into the sand and track closely around individual grains (Shane et al., 2011).

The growing plants secrets many chemical compounds as root exudates to communicate with rhizospheric microbes (Abhilash et al., 2012). Plants are not passive targets for associating organisms, but rather, actively affect the structure of rhizosphere communities by positive and negative effect from their roots (Prithiviraj et al., 2007). Mosse (1973) found that vesicular-arabuscular mycorrhizae improve plant initiation and vigor, especially in case of nutrient deficient in the soil. Mycorrhizal associated to roots have been studied in coastal dunes in several countries, while a few studies on the grasses of coastal dunes (Koske and Halvorson, 1981 and Sylvia, 1986). Bacteria associated with rhizosheaths of different grasses were observed using scanning electron microscopy (SEM) in grasses of Achnatherum hymenoids, Calamovilfa longifolia, Hesperostipa comota and Pascopyrum smithii in sand dunes area. The largest number of bacteria was 
found on rhizosheaths of Calamovilfa longifolia. All examined grasses contained a higher density of bacteria than the surrounding soil (Bergmann et al., 2009).

The spores of endomycorrhizal fungi were formed in the coastal sand dunes and their density being higher in stable than mobile sand (Koske, 1975). As much as $20 \%$ of a plant's net photosynthate is released into the rhizosphere. Large quantities of phenolic compounds are also released from plant roots; approximately $120 \mathrm{~kg} \mathrm{ha}^{-1}$ plant-derived phenolics can be added into grassland soil annually. Many of these strongly affect neighboring plant and microbial communities (Grime, 1977). Extracts and leachates of the grass Aristida adscensionis inhibited the growth of Rhizobium in culture conditions. The results confirm previous studies of the effects of Aristida adscensionis on the nodulation of Indigofera cordifolia (Murthy and Nagodra, 1977). The allelopathic potentialities of Aristida adscensionis Linn. phytoextracted was investigated (Sarma, 1983). The ethyl acetate extracts of the leaves of Aristida pungens L. show a significant antibacterial activity on Pseudomonas and on a large spectra of fungi (Bouhadjera et al., 2005).

The present investigation aimed at studying development of phytogenic hummocks (nabkhas) and canopy of Aristida plumosa, the pioneer plant species in sand dune fixation in North Sinai, and the following sand trapped quantitatively, root and shoot biomass and microorganisms in the rhizosphere and in the surrounding soil. Finally, the allelopathic activity of A. plumosa against Portulaca oleracea weeds and their root exudates profile was determined.

\section{MATERIALS AND METHODS}

\section{Nebkha and Canopy Characteristics}

Nebkha characteristics of Aristida plants during different development periods (15 March, 15 May, 15 July and 15 October, 2014) were studied. 40 similar nebkhas were selected and labeled; nebkha and canopy dimensions were measured.

Nebkha and canopy characteristics were determined according to the procedure of Zhang et al. (2011), where;

Canopy Area $(\mathrm{Ac})=\left(\left[\pi\left(\mathrm{Lc}^{*} \mathrm{Wc}\right)\right] / 4\right)$

Where, $\pi=3.14$

Lc; canopy length

Wc; Canopy width

Nebkha area $(\mathrm{An})=\left(\left[\pi\left(\mathrm{Ln}^{*} \mathrm{Wn}\right)\right] / 4\right)$

Where Ln; Nebkha length

Wn; Nebkha width 
Canopy volume $(\mathrm{Vc})=\left(\left[\pi\left(\mathrm{Lc}^{*} \mathrm{Wc} * \mathrm{Hc}\right)\right] / 6\right)$

Where, Hc; Canopy height

Nebkha Volume $(\mathrm{Vn})=\left(\left[\pi\left(\mathrm{Ln}^{*} \mathrm{Wn} * \mathrm{Hn}\right)\right] / 6\right)$.

Where Hn is Nebkha height

Rate of shoot elongation, $\mathrm{mm} \mathrm{day}^{-1}$ and subsequent sand accumulation rate, $\mathrm{mm}$ day $^{-1}$ were recorded. Volume of trapped sand by nebkhas, $\mathrm{m}^{3},(\mathrm{Vn})$ was multiplied by the sand density of the region $(1640 \mathrm{~kg}$ $\left.\mathrm{m}^{-3}\right)$ to obtain the mass of sand aggregates $(\mathrm{kg})$. A. plumosa plants were gathered with their root system carefully, then sand adherent around roots are then immediately weighed, total length of roots and shoots of all plants constitute the nebkhas were measured. Roots and shoots air dried biomass were determined as $\mathrm{m}^{2}$ in different development stages.

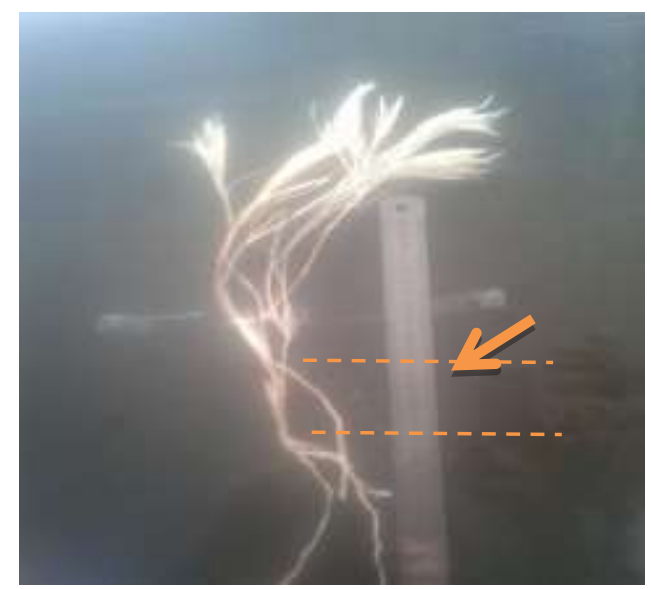

Fig (1). Aristida plumosa

The arrow shows new root formation from nodes (nodal roots) upper; and embryonic roots lower. Dash lines represent different soil levels as a result of sand accumulation.

\section{Microorganisms in the Rhizosphere and the Surrounding Soil}

Soil samples were collected from Baloza area, North Sinai, Egypt, for total microbial counts. Five grams of soil were taken around the $A$. plumosa rhizosphere from selected plant roots, obtained by shaking several times to remove the attached soil particles. Non-rhizosphere soil samples were also taken for microbiological analysis. One gram from each soil sample was placed into $10 \mathrm{ml}$ of distilled water and shaked on a rotary shaker $(100 \mathrm{rpm})$ for $30 \mathrm{~min}$ with five replicates. The resultant microorganism suspension was diluted according to the dilution plate technique (Johnson et al., 1959). Potato dextrose agar medium (PDA; 200.0 $\mathrm{g} \mathrm{l}^{-1}$ potato , $15 \mathrm{~g} \mathrm{l}^{-1}$ agar and $1000 \mathrm{ml}$ distilled water) and nutrient agar

Egyptian J. Desert Res., 66, No. 1, 79-94 (2016) 
medium (3.0 $\mathrm{g} \mathrm{l}^{-1}$ beef extract, $5.0 \mathrm{~g} \mathrm{l}^{-1}$ peptone, $15 \mathrm{~g} \mathrm{l}^{-1}$ agar, $1000 \mathrm{ml}$ distilled water) were prepared according to Jacobs and Gerstein (1960) used for the account of fungi and bacteria, respectively. Incubation was performed at $25 \pm 1^{\circ} \mathrm{C}$ for five days for fungi and $30 \pm 1^{\circ} \mathrm{C}$ for $24 \mathrm{~h}$ for bacteria (Parkinson et al., 1971). The colonies were then counted and different strains were evaluated on the basis of their morphological properties for further investigation, and expressed as Colony Forming Units (CFU) $\mathrm{g}^{-1}$ soil.

\section{Determination of Root Allelochemicals}

The dried roots of A. plumosa (50 g) were ground and soaked in 350 $\mathrm{ml}$ of methanol $(90 \%)$. The extracts obtained were shaked for $24 \mathrm{~h}$ and stored at $4^{\circ} \mathrm{C}$. The extracts were centrifuged at 5,000 rpm for $10 \mathrm{~min}$. Each of these steps were repeated three times and $350 \mathrm{ml}$ of $90 \%$ methanol was added. Rhizosphere soil samples obtained from A. plumosa $(50 \mathrm{~g})$ were extracted with $350 \mathrm{ml}$ of $80 \%$ methanol, three times by shaking for $5 \mathrm{~h}$, at ambient temperature. The extracts were centrifuged at 5,000 rpm for $10 \mathrm{~min}$. The supernatant was transferred with a pipette to a separate test tube. Supernatants were concentrated under vacuum and stored at $4^{\circ} \mathrm{C}$. The weighed crude extracts were re-dissolved for bioassay and analyses by HPLC Thermo, USA). The HPLC ${ }^{\text {SPECTRA SYSTEM }}$ was equipped with a dual pump, an auto sampler, and a UV detector. Samples were run on an analytical $\mathrm{C}_{18}$ column (5 um, $4.6-150 \mathrm{~mm}$ ) using gradient elution. Mobile phase consisted of $0.1 \%(\mathrm{v} / \mathrm{v})$ acetic acid in water (Solution A)-MeOH (Solution B) using the following linear gradient: $10 \%$ to $90 \%$ B over $60 \mathrm{~min}$. The flow rate of the mobile phase was $0.7 \mathrm{ml} \mathrm{min}^{-1}$ and the injection volume was $20 \mathrm{ul}$. UV detection was recorded at $280 \mathrm{~nm}$.

\section{Allelopathy}

Pursalne $(P$. oleracea $)$ seeds were sterilized using sodium hypochlorite $(0.3 \% \mathrm{v} / \mathrm{v})$ for $10-12 \mathrm{~min}$ and washed four times in sterile double-distilled water then placed in Petri dishes. The crude extracts from $A$. plumosa roots and their soil rhizosphere were redissolved in aqueous methanol to give $0,100,200,300$ and $400 \mu \mathrm{g} \mathrm{ml}^{-1}$ for treating plants' seeds. The solvent was replaced with sterilized distilled water, and after seven days from the treatment, seeds germination and seedling growth were recorded.

The effective dose $\left(\mathrm{EC}_{50}\right)$ for each growth parameter was calculated in a semi-log paper. The reduction $(\mathrm{R} \%)$ was calculated from this equation:

Reduction percent $=(\mathrm{C}-\mathrm{T} / \mathrm{C}) \times 100$.

Where; $\mathrm{C}$; control and $\mathrm{T}$; treatments 


\section{Statistical Analysis}

Statistical analysis was computed by using ANOVA according to Snedecor and Cochran (1990). Mean differences were conducted using Duncan Multiple Range using the program of Mstat-C.

\section{RESULTS AND DISCUSSION}

\section{Natural Plant Species of Sand Dunes in North Sinai}

The ecological analysis of the studied sand dune of Crest and Slope and interdunes revealed that, there were twelve species (Mesembryanthemum crystallium, Aristida plumosa, Cornulaca monocantha, Zygophyllum album, Thymelaea hirsuta, Artemisia monosperma, Anabasis articulate, Fagonia indica, Thymus vulgaris, Carpobrotus edulis, Salsola vermiculata, Cynodon dactylon) within twelve genera belonging to six families (Aizoaceae, Poaceae, Amaranthaceae, Zygophyllaceae, Thymelaeaceae, Lamiaceae ) as recorded at Balouza region. Most species were stated in the interdunes. However, only three species were recorded in both crest and the slope of the dunes. The most abundant species were Mesembryanthemum crystallium and Zygophyllum album, while Aizoaceae was the most abundant family recorded in the dune (Table 1).

Table (1). Natural plant species in the studied region.

\begin{tabular}{|c|c|c|c|}
\hline Scientific name & Family & Dune position & $\begin{array}{c}\text { No. of plants/ } \\
100 \mathrm{~m}^{-2}\end{array}$ \\
\hline $\begin{array}{l}\text { Mesembryanthemum } \\
\text { crystallium }\end{array}$ & Aizoaceae & Crest, slope and interdunes & 10,20 and 4 \\
\hline Aristida plumosa & Poaceae & Dune crest & 15 \\
\hline Cornulaca monocantha & Amaranthaceae & Interdunes & 5 \\
\hline Zygophyllum album & Zygophyllaceae & Crest, slope and interdunes & 10,20 and 5 \\
\hline Thymelaea hirsuta & Thymelaeaceae & Interdunes & 8 \\
\hline Artemisia monosperma & Lamiaceae & Interdunes & 10 \\
\hline Anabasis articulata & Aizoceae & Interdunes & 15 \\
\hline Fagonia indica & Zygophyllaceae & Interdunes & 11 \\
\hline Thymus vulgaris & Lamiaceae & Interdunes & 3 \\
\hline Carpobrotus edulis & Aizoaceae & Interdunes & 5 \\
\hline Salsola vermiculata & Amaranthaceae & Interdunes & 5 \\
\hline Cynodon dactylon & Poaceae & Interdunes & 7 \\
\hline
\end{tabular}

\section{Nebkha and Canopy Characteristics}

Aristida plants increased in height from $28 \mathrm{~cm}$ in mid March to 89 $\mathrm{cm}$ in mid October with an increase in sand trapped. Maximum height recorded was $17 \mathrm{~cm}$ in mid March and $42 \mathrm{~cm}$ in mid October, while sand 
mean height was recorded $5.6 \mathrm{~cm}$ in mid March to $13 \mathrm{~cm}$ in mid October (Fig. 2). With accumulation of sand around Aristida plants, they were accelerated their shoot elongation and recorded 2.67, 4.33 and $2.11 \mathrm{~mm}^{-1 a y}{ }^{-1}$ during periods of mid March to mid May, mid May to mid July and mid July to mid October, respectively. Whereas sand trapped rate was recorded 0.50 , 1.67 and $1.33 \mathrm{~mm} \mathrm{day}^{-1}$ during the previous periods, respectively (Fig. 3). A. plumosa nebkha height and root depth were recorded as 89 and $43 \mathrm{~cm}$, respectively, on 15 October 2015 . The nebkha length and width was found to be $75 \mathrm{~cm} \times 45 \mathrm{~cm}$ for the same period, while number of branches recorded at $10 \mathrm{~cm}$ were $52 \mathrm{~cm}$.

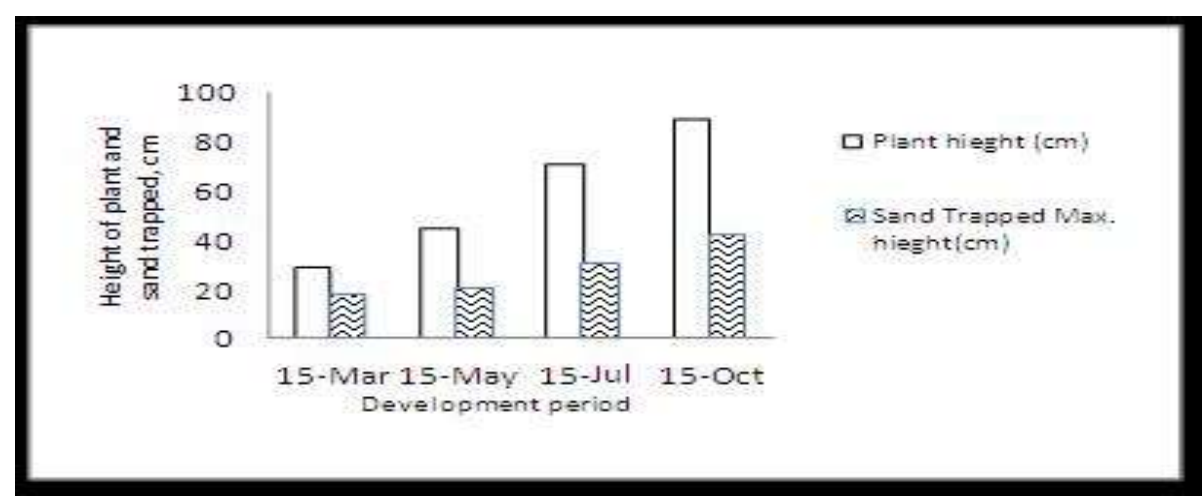

Fig. (2). Height of Aristida plants and sand trapped, cm.

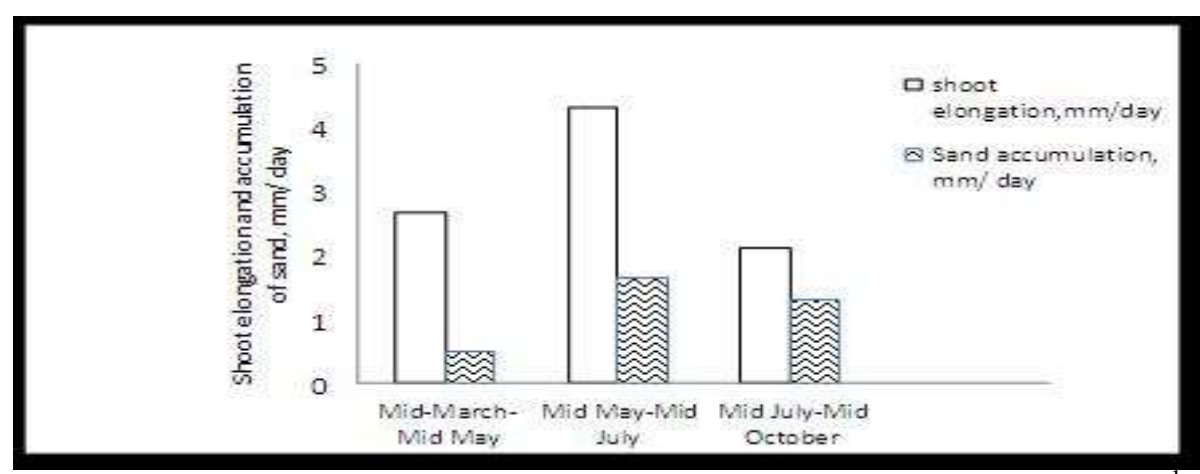

Fig. (3). Aristida shoot elongation and sand accumulation rate, $\mathrm{mm} \mathrm{day}^{-1}$.

Nebkha area (An) increased from $0.01 \mathrm{~m}^{2}$ on 15 March to $0.027 \mathrm{~m}^{2}$ on 15 October, whereas canopy area (Ac) increased from 0.07 to $0.42 \mathrm{~m}^{2}$ in the same periods. However, nebkha volume $(\mathrm{Vn})$ developed from $0.001 \mathrm{~m}^{3}$ to $0.07 \mathrm{~m}^{3}$ in the same time canopy volume $(\mathrm{Vc})$ increased from $0.01 \mathrm{~m}^{3}$ to $0.25 \mathrm{~m}^{3}$, respectively. The sand accumulation recorded by nebkha was 68.8 
$\mathrm{kg}$, shoot air dried biomass was $165.8 \mathrm{~g} \mathrm{~m}^{-2}$, root biomass was $12.82 \mathrm{~g} \mathrm{~m}^{-2}$ and sand aggregate adherent by roots was $7.25 \mathrm{~g} \mathrm{~m}^{-2}$ (Table 2).

Table (2). Nebkha characteristics and subsequent sand trapped in different development periods, 2015.

\begin{tabular}{|c|c|c|c|c|}
\hline Nebkha and canopy characteristics & 15 March & 15 May & 15 July & 15 October \\
\hline Nebkha dimension, $\mathrm{cm}(\mathrm{Hn} \times \mathrm{Ln} \times \mathrm{Wn})$ & $17 \times 20 \times 9$ & $20 \times 50 \times 20$ & $30 \times 60 \times 35$ & $42 \times 75 \times 45$ \\
\hline Canopy dimension, $\mathrm{cm}(\mathrm{Hc} \times \mathrm{Lc} \times \mathrm{Wc})$ & $28 \times 40 \times 21$ & $44 \times 70 \times 40$ & $70 \times 80 \times 50$ & $89 \times 90 \times 60$ \\
\hline Root depth, cm & 13.000 & 25.000 & 35.00 & 43.00 \\
\hline $\begin{array}{r}\text { Branches no./nebkha at } 10 \mathrm{~cm} \text { height } \\
\text { at } 20 \mathrm{~cm} \text { height }\end{array}$ & $\begin{array}{c}6.000 \\
12.000\end{array}$ & $\begin{array}{l}23.000 \\
42.000\end{array}$ & $\begin{array}{c}40.00 \\
105.00\end{array}$ & $\begin{array}{c}52.00 \\
143.00\end{array}$ \\
\hline $\begin{array}{l}\text { Nebkha area }(A n), m^{2} \\
\text { Canopy area }(A c), m^{2}\end{array}$ & $\begin{array}{l}0.010 \\
0.070\end{array}$ & $\begin{array}{l}0.080 \\
0.220\end{array}$ & $\begin{array}{l}0.17 \\
0.31\end{array}$ & $\begin{array}{l}0.27 \\
0.42\end{array}$ \\
\hline $\begin{array}{l}\text { Nebkha volume (Vn), m } \\
\text { Canopy volume (Vc), } \mathrm{m}^{3}\end{array}$ & $\begin{array}{l}0.001 \\
0.010\end{array}$ & $\begin{array}{l}0.010 \\
0.060\end{array}$ & $\begin{array}{l}0.03 \\
0.15\end{array}$ & $\begin{array}{l}0.07 \\
0.25\end{array}$ \\
\hline *Sand trapped Mass (m), kg/ nebkha & 1.640 & 16.400 & 49.20 & 121.36 \\
\hline Total shoot biomass (air dried), $\mathrm{g} / \mathrm{m}^{2}$ & 4.300 & 25.900 & 60.0 & 165.80 \\
\hline Total root biomass (air dried), $\mathrm{g} / \mathrm{m}^{2}$ & 0.280 & 1.750 & 2.80 & 12.82 \\
\hline Sand aggregated adherent by roots, $\mathrm{g} / \mathrm{m}^{2}$ & 0.190 & 0.812 & 1.35 & 7.25 \\
\hline
\end{tabular}

*Density of sand particles of the region, $p=1.64 \mathrm{~g} / \mathrm{cm}^{2}$, then sand mass calculated by $\mathrm{m}=\mathrm{p} * \mathrm{v}$

The results indicate that the increase of A. plumosa nebkha growth was increased their abilities to trapp sand by its foliage and catching sand by its roots. With increasing accumulation of sand around Aristida plants, canopy and nebkha dimensions and area are increased. These results are in accordance with Moreno-Casasola (1986), Barbour et al. (1984) and GreigSmith (1964). In addition, rhizosheaths may be an adaptation to nutritional stress and dry conditions of sand dunes (Wullstein et al., 1979; Barbour et al., 1987 and Metcalf, 1960). This sand sheath in sanding roots may help in protection against desiccation and heat stress especially during summer (Shane et al., 2010). It was noticed that new roots were formed in the basal nodes of buried shoots (Fig. 1), which means increase in sand binding

Egyptian J. Desert Res., 66, No. 1, 79-94 (2016) 
ability, subsequently more dune stabilization capability. Consequently, it appears to be an ideal plant for sand dune fixation.

\section{Allelopathic Effect of $A$. plumosa against $P$. oleracea Weed}

As shown in table (3), the highest concentration of A. plumosa root extracts at $400 \mu \mathrm{g} \mathrm{ml}^{-1}$ completely suppressed $P$. oleracea seeds germination and seedling growth. The treatment with 200 and $300 \mu \mathrm{g} \mathrm{ml}{ }^{-1}$ have significantly inhibitory effects upon $P$. oleracea reached 41.1 and $66.7 \%$ (germination), 52.9, 76.5\% (root length) and 36.4 and 77.3\% (shoot length), respectively. On the other hand, the extract of soil rhizosphere at 100, 200, 300 and $400 \mu \mathrm{g} \mathrm{ml}^{-1}$ were recorded a significant reduction in $P$. oleracea germination $(21.5,28.0,67.7,81.7 \%)$, root length $(33.3,72.2,77.8,88.9 \%)$ and shoot length $(25.6,53.8,64.1,74.4 \%)$, respectively. The overall mean shoot length, root length and germination of $P$. oleracea seeds did not differ significantly by both of root extracts and rhizosphere extractions. As the concentration increased from 100 to $400 \mu \mathrm{g} \mathrm{ml}^{-1}$ resulted in a significant reduction in the mean shoot, root length and germination of $P$. oleracea, comparing with the control. The obtained results revealed that increasing concentrations from 100 to $400 \mu \mathrm{g} \mathrm{ml}^{-1}$ for both root and rhizosphere extracts significantly increased the inhibition of root, shoot length and seed germination comparing with control treatment.

The $\mathrm{EC}_{50}$ of A. plumosa methanol extracts was $211 \pm 2,200 \pm 1$ and $240 \pm 2 \mu \mathrm{g} \mathrm{ml}^{-1}$ for $P$. oleracea shoot length $(\mathrm{cm})$, root length $(\mathrm{cm})$, and germination \%, respectively. On the other hand, the $\mathrm{EC}_{50}$ of methanol soil rhizosphere extracts was $245 \pm 3,186 \pm 4$ and $248 \pm 3 \mu \mathrm{g} \mathrm{ml}^{-1}$ for P. oleracea shoot length, root length and germination \%, respectively. According to $\mathrm{EC}_{50}$, the negative effect observed in $P$. oleracea root growth traits was higher from root extracts than soil rhizosphere extracts, whereas shoot length and germination of $P$. oleracea were more affected by rhizosphere extracts than root extracts, as shown in fig. (4).

The root exudates secretion is one of the ways for plant communication to the neighboring plant and adjoins of microorganisms present in the rhizosphere of the roots. Secretion of such exudates may regulate the neighboring soil microbial community, cope with herbivores, inhibit the growth of competitive plant species and change the chemical and physical properties of the soil (Balah, 2015 and Shukla et al., 2011).

\section{Phenolic Compounds Determination in Root Tissue and Soil Rhizosphere Extracts}

Phenolic compounds were extracted with $90 \%$ methanol from $A$. plumosa roots and their rhizosphere soils. While, the authentic compounds were chosen depending on notable phytochemicals about Aristida species 
literature (Sarma, 1983). The chromatographic analysis refers to the detected compounds, namely; gallic acid, catechin, ferulic acid, syringic acid, coumaric acid, resorcinol, caffeic acid, cinnamic acids, kaempferol in root parts. Whereas, rhizospheric soil profile presented ferulic acid, resorcinol, and coumaric acid. It is clearly indicated that root extracts had the higher amount than rhizospheric soil extracts from the same compounds as shown in table (4).

Table (3). Effect of A. plumosa on seed germination and seedling development of P. oleracea plants.

\begin{tabular}{|c|c|c|c|c|}
\hline Treatment & $\begin{array}{c}\text { Concentration } \\
\left(\mu \mathrm{g} \mathrm{ml}^{-1}\right)\end{array}$ & $\begin{array}{c}\text { Germination } \\
(\%)\end{array}$ & $\begin{array}{l}\text { Root length } \\
\text { (cm) }\end{array}$ & $\begin{array}{c}\text { Shoot } \\
\text { length }(\mathrm{cm})\end{array}$ \\
\hline & Control & $90.00(0.0)$ & $1.70(0.0)$ & $4.40(0.0)$ \\
\hline Root parts & 100 & $77.00(14.4)$ & $1.40(17.6)$ & $3.20(27.3)$ \\
\hline \multirow[t]{5}{*}{ extraction (A) } & 200 & $53.00(41.1)$ & $0.80(52.9)$ & $2.80(36.4)$ \\
\hline & 300 & $30.00(66.7)$ & $0.40(76.5)$ & $1.00(77.3)$ \\
\hline & 400 & $0.00(100.0)$ & $0.00(100.0)$ & $0.00(100.0)$ \\
\hline & LSD 0.05 & 14.12 & 0.11 & 0.11 \\
\hline & $\begin{array}{l}\text { Trend line } \\
\text { equation }\end{array}$ & $\begin{array}{c}y=25.222 x- \\
31.222\end{array}$ & $\begin{array}{c}\mathrm{y}=25.882 \mathrm{x} \\
28.235\end{array}$ & $\begin{array}{c}y=25 x- \\
26.818\end{array}$ \\
\hline & Control & $93.00(0.0)$ & $1.80(0.0)$ & $3.90(0.0)$ \\
\hline Soil & 100 & $73.00(21.5)$ & $1.20(33.3)$ & $2.90(25.6)$ \\
\hline rhizosphere & 200 & $67.00(28.0)$ & $0.50(72.2)$ & $1.80(53.8)$ \\
\hline \multirow[t]{5}{*}{ extraction (B) } & 300 & $30.00(67.7)$ & $0.40(77.8)$ & $1.40(64.1)$ \\
\hline & 400 & $17.00(81.7)$ & $0.20(88.9)$ & $1.00(74.4)$ \\
\hline & LSD 0.05 & 9.68 & 0.19 & 0.19 \\
\hline & $\begin{array}{c}\text { LSD } 0.05 \mathrm{~A} \times \\
\mathrm{B}\end{array}$ & 13.68 & 0.27 & 0.27 \\
\hline & $\begin{array}{c}\text { Trend line } \\
\text { equation }\end{array}$ & $\begin{array}{l}y=20.968 x- \\
23.118\end{array}$ & $\begin{array}{l}y=22.222 x- \\
12.222\end{array}$ & $\begin{array}{l}y=18.718 x \\
-12.564\end{array}$ \\
\hline
\end{tabular}

Values between brackets is the reduction percent.

\section{Microorganisms (Bacteria and Fungi) Density in Dune Sand of Balouza}

Bacterial count was significantly higher than number of fungi in the soil near A. plumosa grass; it recorded 42.4 and $8.83 \mathrm{cfu} \mathrm{g}^{-1}$, respectively. However, total microorganisms density was significantly higher in rhizosphere compared with non-rhizospheric samples, it recorded 36.83 and $14.42 \mathrm{cfu} \mathrm{g}^{-1}$, respectively (Table 5). 


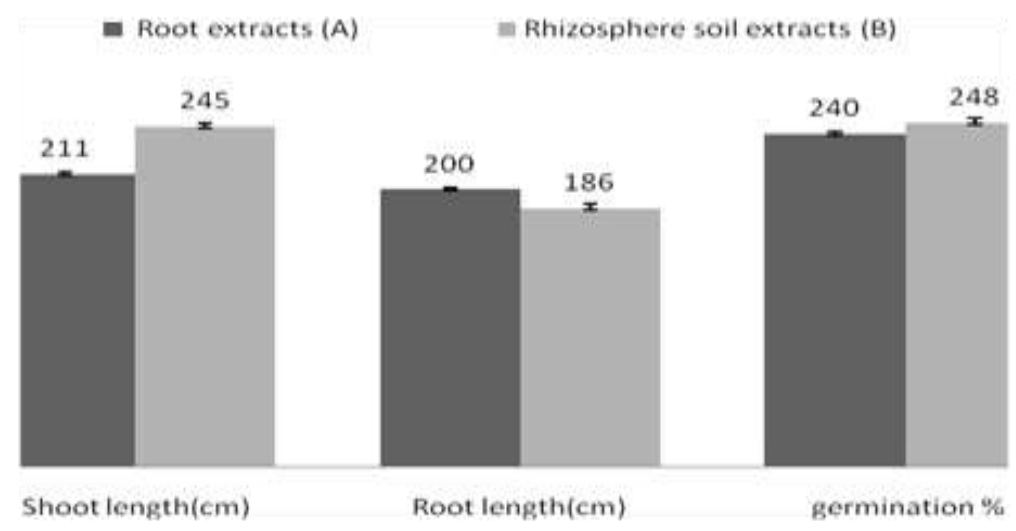

Fig (4). Dose response relationship (EC ${ }_{50}$ ) of root and soil rhizosphere extracts of $P$. oleracea $\left(\mu \mathrm{g} \mathrm{ml}^{-1} \pm\right.$ Standard division $)$.

Table (4). The content of phenols in A. plumosa root tissue and associated rhizosphere soils.

\begin{tabular}{lccc}
\hline Authentic samples & RT $(\mathbf{m i n})$. & $\begin{array}{c}\text { Roots tissue } \\
(\mathbf{m g} / \mathbf{k g})\end{array}$ & $\begin{array}{c}\text { Rhizosphere soil } \\
(\mathbf{m g} / \mathbf{k g})\end{array}$ \\
\hline Gallic acid & 3.80 & 0.5000 & $\mathrm{ND}$ \\
Catechin & 6.00 & 0.382 & $\mathrm{ND}$ \\
Ferulic acid & 15.80 & 0.409 & 0.0122 \\
Syringic acid & 24.30 & 0.270 & $\mathrm{ND}$ \\
Coumaric acid & 32.80 & 1.330 & 0.8770 \\
Resorcinol & 34.50 & 1.106 & 0.4870 \\
Caffeic acid & 45.10 & 0.820 & $\mathrm{ND}$ \\
Cinnamic acids & 46.63 & 0.170 & $\mathrm{ND}$ \\
Kaempferol & 48.90 & 0.230 & $\mathrm{ND}$ \\
Total amount & & 5.217 & 1.3760 \\
\hline
\end{tabular}

Table (5). Microorganisms density near A. plumosa in dune sand of Balouza.

\begin{tabular}{lcccc} 
& Fungi & Bacteria & Rhizosphere & $\begin{array}{c}\text { Non- } \\
\text { Rhizosphere }\end{array}$ \\
\cline { 2 - 5 } Count & $8.83 \mathrm{~b}$ & $42.42 \mathrm{a}$ & $36.83 \mathrm{a}$ & $14.42 \mathrm{~b}$ \\
(CFU) & & & & \multicolumn{2}{c}{5.25} \\
LSD 0.05 & \multicolumn{2}{c}{5.25} & & \multicolumn{2}{c}{} \\
\hline
\end{tabular}

Bacteria in rhizosphere recorded the highest significant value followed by bacteria in the non-rhizosphere, as compared to fungi in both rhizosphere and non-rhizosphere; it recorded 61.83, 23.00, 11.83 and 5.83 
cfu $\mathrm{g}^{-1}$, respectively. Bacteria at dilution of $10^{-3}$ recorded the highest significant value, followed by bacteria at dilution of $10^{-4}$ compared with fungi at both dilutions of $10^{-3}$ and $10^{-4}$, it recorded 52.0, 32.8, 12.3 and 5.3 cfu $\mathrm{g}^{-1}$, respectively. It is obvious that bacteria in the rhizosphere at dilution of $10^{-3}$ recorded the highest value, followed by rhizosphere bacteria at dilution of $10^{-4}$, it recorded 74.00 and $49.67 \mathrm{cfu} \mathrm{g}^{-1}$, respectively. However, non-rhizosphere fungi at dilution of $10^{-4}$ recorded the lowest value of 3.33 cfu $\mathrm{g}^{-1}$ (Table 6). The results are in agreement with those obtained by Bergmann et al. (2009) and Koske (1975).

Table (6). Microorganisms density near A. plumosa plants in dune sand of Balouza.

\begin{tabular}{ccccccc}
\hline & & Fungi & & \multicolumn{3}{c}{ Bacteria } \\
\hline Dilution & $\mathrm{R}$ & $\mathrm{NR}$ & Mean & $\mathrm{R}$ & $\mathrm{NR}$ & Mean \\
$10^{-3}$ & $16.33 \mathrm{~d}$ & $8.33 \mathrm{de}$ & $12.33 \mathrm{c}$ & $74.00 \mathrm{a}$ & $30.00 \mathrm{c}$ & $52.00 \mathrm{a}$ \\
$10^{-4}$ & $7.33 \mathrm{de}$ & $3.33 \mathrm{e}$ & $5.33 \mathrm{~d}$ & $49.67 \mathrm{~b}$ & $16.00 \mathrm{~d}$ & $32.83 \mathrm{~b}$ \\
Mean & $11.83 \mathrm{c}$ & $5.83 \mathrm{c}$ & & $61.83 \mathrm{a}$ & $23.00 \mathrm{~b}$ &
\end{tabular}

LSD 0.05 $\mathrm{ABC}=9.23, \mathrm{AB}=7.43, \mathrm{AC}=6.53 \mathrm{~A}=$ microorganism (fungi, bacteria), $\mathrm{B}=$ distance from root $(\mathrm{R}, \mathrm{NR}), \mathrm{C}=$ concentration $\left(10^{-3}, 10^{-4}\right)$

The mycorrhizal fungi may contribute to sand dune stabilization by linking sand grains in aggregates with fungal hyphae, which may serve in drought resistance and improve plant establishment in desert dunes as studied by Sutton and Sheppard (1976). In this study, the fungal isolates were identified according to Anonymous (2003 and 2005), five isolates were Aspergillus and Penicillum in addition six Actinomycetes isolates (mostly Streptomyces). On the other hand, the eleven bacterial isolates need further studies to be identified.

\section{CONCLUSION}

Natural plant vegetation plays an important ecological role in sand dune areas especially in sand dune stabilization. The majority of dune plant species in the study region was situated in the interdunes. However, only three species were found in both crest and the slope of the dunes. During the present study, A. plumosa (Poaceae) attracted attention through their growth characters, especially root formation and root sheaths ability to catch sands. This plant has the ability to generate new adventitious roots from nodes at the base of buried nodes to produce new plants attached with the mother plants; that permits plants to share the assimilation products. In addition to their root exudates with their associated microbes that adhering sand 
particles around roots resulting in binding sand layers. All these formations increased the ability of A. plumosa to catch sands and stabilize the dune. The allelopathic activity of $A$. plumosa root parts was evaluated against $P$. oleracea weeds, in which increasing concentrations of root parts and soil rhizosphere extracts increased the suppressive ability against $P$. oleracea root, shoot length and seed germination. Total microorganisms density was significantly higher in rhizosphere compared with non-rhizospheric samples. However, the bacterial count was significantly higher than the number of fungi in the soil near A. plumosa grass. Quantitative analysis by HPLC/UV showed nine phenol compounds in root parts. However, only three compounds were detected in rhizospheric soil extracts. Further study are needed to identify all phytochemicals and soil microorganism. On the other hand, A. plumose exhibited superior natural growth characteristics (vegetative and subterranean growth, their rhizosheath, root branches, structural and exudates) that facilitate its ability to form nebkha sands and face the scarcity of water, nutrient deficiency making this an ideal plant for stabilizing sands.

\section{REFERENCES}

Abhilash, P.C., J.R. Powell, H.B. Singh and B.K. Singh (2012). Plantmicrobe interactions: novel applications for exploitation in multipurpose remediation technologies. Trends Biotechnol, 30 (8): 416-20.

Anonymous (2003). Fungal Genomics Project, Concordia University. https://fungalgenomics.concordia.ca/fungi/Pchr.php .

Anonymous (2005). Organization for Economic Co-operation and Development. http://appli1.oecd.org/olis/2005doc.

Balah, M.A. (2015). Allelopathic effects of Bindweed (Convolvulus arvensis L.) root exudates on plants and soil Microflora. Journal of Egyptian Desert Research, 65 (1):31-46.

Barbour, M.G., T.D. Jong and B.M. Pavlik (1984). In "Maine Beach and Dune Plant Communities. Chabot B. and H. Mooney (eds.). Physiological Plant Ecology of North American Plant Communities. Chapman and Hall Publisher.

Barbour, M.G., J.H. Burk and W.D. Pitts (1987). Terrestrial plant ecology. $2^{\text {nd }}$ ed. The Benjamin/Cummings Publishing Company, Inc., Reading, Maine.

Bergmann, D., M. Zehfus, L. Zierer, B. Smith and M. Gabel (2009). Grass rhizosheaths: Associated bacterial communities and potential for nitrogen fixation. Western North American Naturalist, 69 (1): 105114. 
Boulos, L. (1960). In "Flora of Gebel El-Maghara, North Sinai". The Herbarium, Ministry of Agriculture, Egypt. General Organization for Government Printing Offices, Cairo, Egypt.

Bouhadjera, K., M. Bendahou and B. Tabti (2005). Anti-microbial Activity of extracts from Algerian Aristida pungens L. Pakistan Journal of Biological Sciences, 8: 206-210.

Danin, A. (1991). Plant adaptations in desert dunes. J. Arid Environ., 21: 193-212.

Danin, A. (1996a). In "Plants of Desert Dunes". Springer-Verlag, Berlin Heidelberg, p.146-148.

Danin, A. (1996b). Adaptations of Stipagrostis species to desert dunes. J. Arid Environ., 34: 297-311.

Elkharbotly, A. (2013). Influence of stabilization processes on some ecological features of Balouza sand dune area, North Sinai, Egypt. Bull. NRC., 38 (2): 97-111.

Gazar, M.H., A.A. Moustafa and W.M. Kamel (2000). Ecological notes and floristic composition of Gebel El-Halal, North Sinai, Egypt. Bulletin of Faculty of Science, Assiut University, 29: 323-334.

Greig-Smith, P. (1964). In "Quantative Plant Ecology". $3^{\text {rd }}$ ed. Blackwell Scientific Publications, Oxford.

Grime, J.P. (1977). Evidence of the existence of three primary strategies in plants and its relevance in ecological and evolutionary theory. Am. Nat., 111: 1169-1194.

Hesp, P.A. (1991). Ecological processes and plant adaptations on coastal dunes. J. Arid Environ., 21: 165-191.

Jacobs, M.B. and M.J. Gerstein (1960). In "Handbook of Microbiology". De Van Nostranal Co. Inc., New York, p.139-202.

Johnson, L.F., E.A. Curl, J.H. Band and H.A. Fribourg (1959). In "Methods for Studying Soil Microflora- Plant Disease Relationships". Burgess, Minneapolis, p. 12-20.

Koske, R.E. (1975). Endogone spores in Australian sand dunes. Canadian J. of Botany, 53 (7): 668-672.

Koske, R.E. and W.L. Halvorson (1981). Ecological studies of vesiculararbuscular mycorrhizal in a barrier sand dune. Canadian J. of Botany, 59 (8): 1413-1422.

Metcalf, C.R. (1960). In "Anatomy of Monocotyledons, I. Gramineae". Clarendon Press, Oxford, p. 283-285.

Moreno-Casasola, P. (1986). Sand movement as a factor in the distribution of plant communities in a coastal dune system. Vegetation, 65 (2): $67-$ 76.

Mosse, B. (1973). Plant growth response to vesicular-arbuscular mycorrhizal. New Phytologist, 72 (1): 127-136.

Egyptian J. Desert Res., 66, No. 1, 79-94 (2016) 
Murthy, M.S. and T. Nagodra (1977). Allelopathic Effects of Aristida adscensionis on Rhizobium. Journal of Applied Ecology, 14: 279-282.

Parkinson, P., T.R.G. Gray and S.T. William (1971). In "Methods for Studying the Ecology of Soil Microorganisms". Blackwell Scientific Publication Oxford, 116 pp.

Prithiviraj, B., L.G. Perry, D.V. Badri, and J.M. Vivanco (2007). Chemical facilitation and induced pathogen resistance mediated by a rootsecreted phytotoxin. New Phytologist, 173: 852-860.

Sarma, K.V. (1983). Allelopathic potential of the phytoextracts of Aristida adscensionis Linn. Tropical Ecologyer, 24 (1): 19-21.

Shane M.W., M.E. McCully and M.J. Canny (2010). Seasonal water relations of Lyginia barbata (Southern rush) in relation to root xylem development and summer dormancy of root apices. New Phytologist, 185: 1025-1037.

Shane, M.W., M.E. McCully, M.J. Canny, J.S. Pate and H. Lambers (2011). Development and persistence of sand sheaths of Lyginia barbata (Restionaceae): relation to root structural development and longevity. Annals of Botany, 108: 1307-1322.

Shukla, K.P., S. Sharma, N.K. Singh, V. Singh, K. Tiwari and S. Singh (2011). Nature and role of root exudates: efficacy in bioremediation. African J. of Biotechol., 10 (48): 9717-9724.

Snedecor, G.W. and W.G. Cochran (1990). In "Statistical Methods". $8^{\text {th }}$ Ed. Iowa State Univ. Press, Ames, Iowa, U.S.A.

Sutton, J.C. and B.R. Sheppard (1976). Aggregation of sand dune soil by endomycorrhizal fungi. Canadian J. of Botany, 54 (3-4): 326-333.

Sylvia, D.M. (1986). Spatial and temporal distribution of vesiculararbuscular mycorrhizal fungi associated with Uniola paniculata in Florida foredunes. Mycologia, 78: 728-734.

Täckholm, V. (1974). In "Students' Flora of Egypt". Published by Cairo University, printed by Cooper Native printing Co., Beirut. 888 pp.

Wullstein, L.H., M.L. Bruening and W.B. Ballen (1979). Nitrogen fixation associated with sand grain root sheaths (Rhizosheaths) of certain xeric grasses. Physiol. Plantarum, 46: 1-4.

Zhang, P., J.L. Yang, Zhao, S. Bao and B. Song (2011). Effect of Caragana tibetica nebkhas on sand entrapment and fertile islands in steppedesert ecotones on the Inner Mongolia Plateau, China. Plant Soil, 347: 79-90.

Received: 11/7/2016

Accepted: 31/10/2016 


\section{الأريستيدا بلوموزا: التأثير الأليلوباثي والقدرة على تثبيت الرمال في

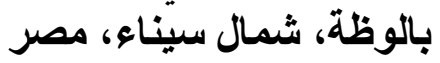

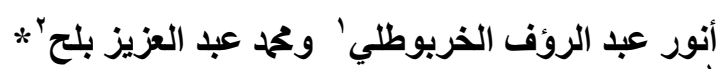

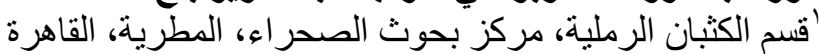

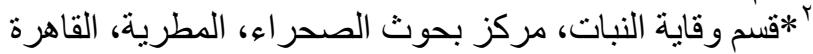

يهدف هذا البحث إلى إلقاء الضوء على أهية نبات Aristida plumosa كنبات مثالي

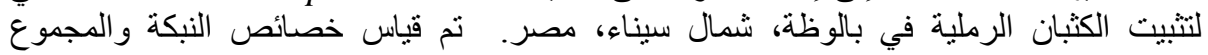

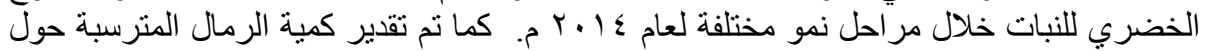

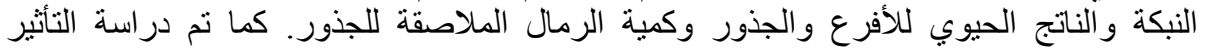

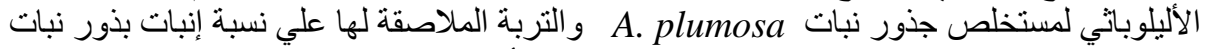

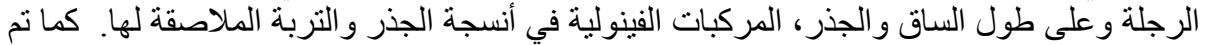

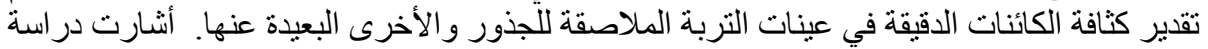

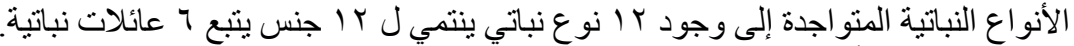

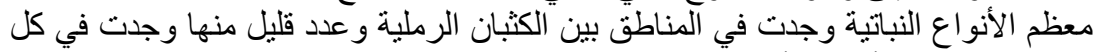

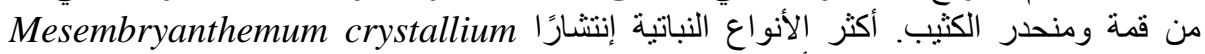

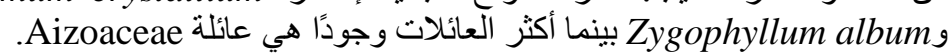

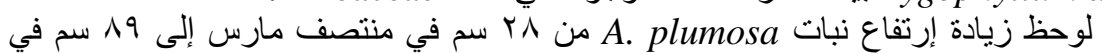

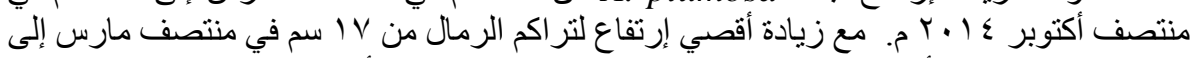

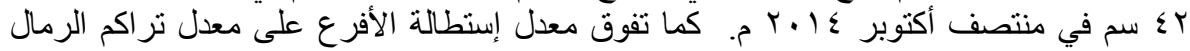

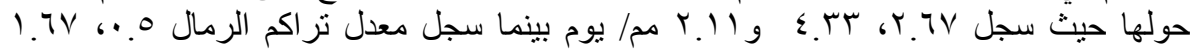

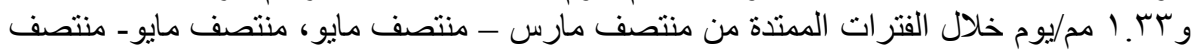

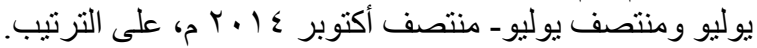

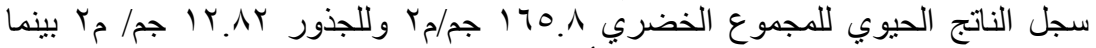

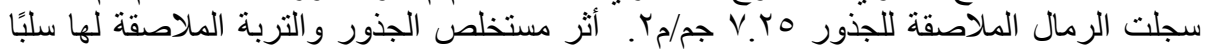

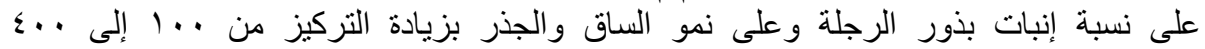

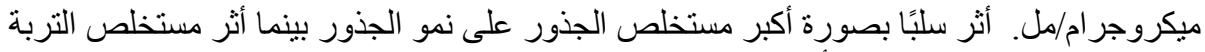

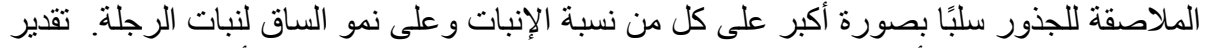

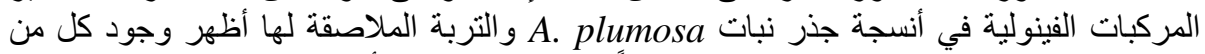

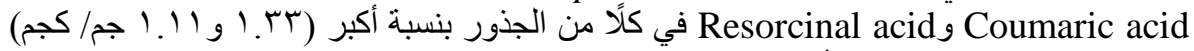

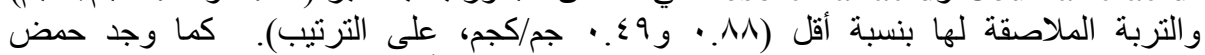
Ferulic acid بنسبة قليلة في الجذور (Vinnamic acid

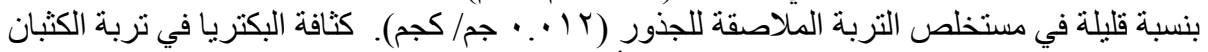
الرملية الملاصقة لنبات A. plumosa كانت أعلى من كثافة الفطريات، كما زادت التهات الكثافة الكلية

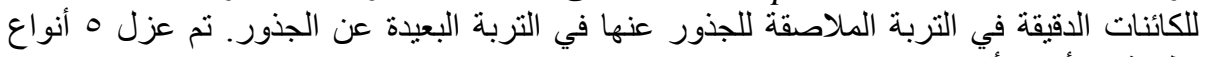

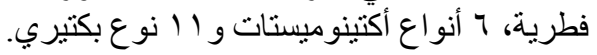

Egyptian J. Desert Res., 66, No. 1, 79-94 (2016) 